\title{
Heat of Formation of Potassium Calcium Silicate
}

\author{
Edwin S. Newman
}

\begin{abstract}
The heats of solution of $2 \mathrm{CaO} \cdot \mathrm{SiO}_{2}(\mathrm{c}, \beta), \mathrm{CaSO}_{4}$ (c, anhydrite), $\mathrm{K}_{2} \mathrm{SO}_{4}$ (c, II) and six members of a series of substitutional solid solutions of $\mathrm{K}_{2} \mathrm{O}$ in dicalcium silicate were determined in a nitric-hydrofluoric acid mixture by means of an isothermal-jacket calorimeter. From these data and heats of formation taken from the literature, the heat of formation of $\mathrm{K}_{2} \mathrm{O} \cdot 23 \mathrm{CaO} \cdot 12 \mathrm{SiO}_{2}$ (c) was calculated to be $-6,420$ kilocalories per mole at $25^{\circ} \mathrm{C}$.
\end{abstract}

\section{Introduction}

As part of a continuing investigation of the thermochemical properties of substances occurring in hydraulic cements and their reaction products, the heat of formation of $\mathrm{K}_{2} \mathrm{O} \cdot 23 \mathrm{CaO} \cdot 12 \mathrm{SiO}_{2}$, abbreviated $\mathrm{KC}_{23} \mathrm{~S}_{12},{ }^{1}$ has been determined. No prior thermochemical data for this compound have been found.

Measurements were made at $25^{\circ} \mathrm{C}$ of $-\Delta \mathrm{H}$, the heat evolved in the reaction

$$
\begin{array}{r}
\mathrm{K}_{2} \mathrm{O} \cdot 23 \mathrm{CaO} \cdot 12 \mathrm{SiO}_{2}(\mathrm{c})+\mathrm{CaSO}_{4}(\mathrm{c}, \text { anhydrite }) \longrightarrow \\
12\left(2 \mathrm{CaO} \cdot \mathrm{SiO}_{2}\right)(\mathrm{c}, \beta)+\mathrm{K}_{2} \mathrm{SO}_{4}(\mathrm{c}, \mathrm{II}) .
\end{array}
$$

This reaction occurs spontaneously at high temperature $[1],{ }^{2}$ where, however, the high-temperature form of $\mathrm{CaSO}_{4}$ is present and liquid $\mathrm{K}_{2} \mathrm{SO}_{4}$ is formed. The value of $-\Delta \mathrm{H}$ was obtained by measuring the heats of solution of these four substances in a mixture of nitric and hydrofluoric acid solutions. The heat of formation of $\mathrm{KC}_{23} \mathrm{~S}_{12}$ at $25^{\circ} \mathrm{C}$ was calculated from the heat of the reaction and the heats of formation of the other three substances taken from the literature.

\section{Materials, Apparatus, and Procedure}

Analytical reagents were used in all preparations. Dicalcium silicate, $\mathrm{C}_{2} \mathrm{~S}$, was made by the repeated heating at $1,450^{\circ} \mathrm{C}$ and dusting ${ }^{3}$ of a mixture of low-alkali $\mathrm{CaCO}_{3}$ and silicic acid. This material was stablized in the beta form by the addition of about 0.5 percent of $\mathrm{B}_{2} \mathrm{O}_{3}$ as $\mathrm{H}_{3} \mathrm{BO}_{3}$ and further heating and grinding. The final product was ground rapidly to pass a No. 100 sieve and stored in a desiccator over magnesium perchlorate and Ascarite.

Potassium sulfate was ground to pass a No. 100 sieve and heated overnight at $220^{\circ} \mathrm{C}$. Precipitated gypsum was heated overnight at $1,000^{\circ} \mathrm{C}$ to convert it to anbydrite. Both of these materials were also stored in the desiccator until tested.

\footnotetext{
1 The customary abbreviations $\mathrm{C}$ for $\mathrm{CaO}$, $\mathrm{K}$ for $\mathrm{K}_{2} \mathrm{O}$, and $\mathrm{S}$ for $\mathrm{SiO}_{2}$ will be used.

2 Figures in brackets indicate the literature references at the end of this paper. ${ }^{3}$ In the absence of stabilizers, the beta form of $\mathrm{C}_{2} \mathrm{~S}$ inverts to the gamma form at room temperature. The 10-percent increase in volume accompanying this inversion results in the disintegration or "dusting" of the particles into a fine powder. When a stabilizer is added, this dusting does not occur, and grinding is necessary to obtain a powdered material.
}

The potassium-containing compound in portland cement clinker, identified by Taylor [2] as $\mathrm{KC}_{23} \mathrm{~S}_{12}$, is now believed to be a solid solution [3] in which $\mathrm{K}_{2} \mathrm{O}$ is partially substituted for the $\mathrm{CaO}$ in dicalcium silicate. To prepare a series of such solid solutions, six mixtures of $\mathrm{CaCO}_{3}$, silicic acid, and a glass of the composition $\mathrm{K}_{2} \mathrm{O} \cdot 4 \mathrm{SiO}_{2}$ were heated repeatedly at $1,450^{\circ} \mathrm{C}$ with intervening grinding. These mixtures were prepared with various amounts of $\mathrm{K}_{2} \mathrm{O}$, the molar ratio of $\left(\mathrm{CaO}+\mathrm{K}_{2} \mathrm{O}\right) / \mathrm{SiO}_{2}$ being maintained at 24/12 (table 1). When microscopical examination indicated that each of these preparations consisted of a single phase, they were rapidly ground to pass a No. 100 sieve and stored in the desiccator until their heats of solution had been determined. The samples were analyzed by the conventional methods for portland cement [4], except that in the determination of $\mathrm{SiO}_{2}$ in the dicalcium silicate sample, boron was removed by repeated evaporation with methyl alcohol.

The calorimeter and details of its operations have been described previously $[5,6,7]$, but a number of minor changes have been made. The heater now consists of a $90-\mathrm{ohm}$ coil of No. 32 double-silk insulated alloy wire in a platinum tube about $5 / 32$ in. in diameter and 5 in. long. A 4-blade platinum propeller-type stirrer is used in a platinum stirring tube, and the reaction vessel and its cover have been lined with sheet platinum. The heater current, from a bank of storage batteries, is controlled by means of one blade of a 50-amp double-pole double-throw spring toggle switch. Current from a dry cell through the other blade of the switch actuates one pen of a 3-pen tape chronograph. A second pen inscribes a standard seconds signal on the tape which travels at about $1 \mathrm{~cm} / \mathrm{sec}$. The maximum timing error probably does not exceed $0.03 \mathrm{sec}$ in $10 \mathrm{~min}$, or 1 part in 20,000. When the switch is in the off position, the heater current is stabilized by discharge through an external resistor. The heater current and voltage, about $0.2 \mathrm{amp}$ and $18 \mathrm{v}$, respectively, are measured by means of a high-precision potentiometer, a standard 1-ohm resistor, and a volt box. These resistors have been calibrated from time to time by the Electrical Division of the Bureau. Temperature rises are measured with a platinum resistance thermometer, a Mueller $\mathrm{G}-1$ bridge, and a high-ser sitivity galvanometer with an optical lever of about $8 \mathrm{~m}$. The apparatus is located in a constant- 
TABle 1. Analyses of preparations

\begin{tabular}{|c|c|c|c|c|c|c|c|c|}
\hline & \multicolumn{8}{|c|}{ Sample } \\
\hline & $\beta-\mathrm{C}_{2} \mathrm{~S}$ & A & B & $\mathrm{C}$ & $\mathrm{D}$ & $\mathrm{E}$ & $\mathrm{F}$ & $\mathrm{G}^{2}$ \\
\hline $\begin{array}{l}\mathrm{SiO}_{2} \\
\mathrm{R}_{2} \mathrm{O}_{3} \\
\mathrm{CaO} \\
\mathrm{MgO} \\
\mathrm{K}_{2} \mathrm{O}_{\ldots} \\
\mathrm{Na}_{2} \mathrm{O}\end{array}$ & $\begin{array}{r}\% \\
34.42 \\
0.10 \\
65.01 \\
.02 \\
\end{array}$ & $\begin{array}{c}\% \\
34.54 \\
0.28 \\
64.42 \\
0.47 \\
.05\end{array}$ & $\begin{array}{c}\% \\
34.56 \\
0.26 \\
64.16 \\
0.93 \\
.05\end{array}$ & $\begin{array}{c}\% \\
34.62 \\
0.30 \\
63.32 \\
1.69 \\
.06\end{array}$ & $\begin{array}{c}\% \\
34.34 \\
0.12 \\
62.46 \\
2.95 \\
.06\end{array}$ & $\begin{array}{c}\% \\
34.72 \\
0.32 \\
59.34 \\
5.65 \\
.09\end{array}$ & $\begin{array}{c}\% \\
34.84 \\
0.18 \\
60.66 \\
4.30 \\
.08\end{array}$ & $\begin{array}{c}\% \\
33.99 \\
61.14 \\
4.16\end{array}$ \\
\hline $\begin{array}{l}\text { Total } \\
\mathrm{K}_{2} \mathrm{O} \text { lost }\end{array}$ & 99.55 & $\begin{array}{l}99.76 \\
18\end{array}$ & $\begin{array}{l}99.96 \\
18\end{array}$ & $\begin{array}{l}99.99 \\
25\end{array}$ & $\begin{array}{l}99.93 \\
34\end{array}$ & $\begin{array}{l}100.12 \\
36\end{array}$ & $\begin{array}{l}100.06 \\
35\end{array}$ & $\begin{array}{l}99.29 \\
57\end{array}$ \\
\hline \multicolumn{9}{|c|}{ Molar proportions } \\
\hline $\begin{array}{l}\mathrm{CaO} \\
\mathrm{K}_{2} \mathrm{O} \\
\mathrm{SiO}_{2} \\
\left(\mathrm{~K}_{2} \mathrm{O}+\mathrm{CaO}\right)\end{array}$ & $\begin{array}{l}24.27 \\
12.00\end{array}$ & $\begin{array}{l}23.97 \\
0.104 \\
12.00 \\
24.07\end{array}$ & $\begin{array}{l}23.86 \\
0.206 \\
12.00 \\
24.07\end{array}$ & $\begin{array}{l}23.51 \\
0.373 \\
12.00 \\
23.88\end{array}$ & $\begin{array}{l}23.38 \\
0.657 \\
12.00 \\
2 \unlhd .04\end{array}$ & $\begin{array}{l}21.96 \\
1.245 \\
12.00 \\
23.20\end{array}$ & $\begin{array}{l}22.38 \\
0.944 \\
12.00 \\
23.32\end{array}$ & $\begin{array}{l}23.12 \\
0.936 \\
12.00 \\
23.05\end{array}$ \\
\hline
\end{tabular}

aThis sample prepared from $\mathrm{K}_{2} \mathrm{CO}_{3}, \mathrm{CaCO}_{3}$, and silicic acid.

temperature room operated at $25.0 \pm 0.5^{\circ} \mathrm{C}$ during calorimetric measurements. Temperature readings are taken at 2 -min intervals during the rating periods and at 1-min intervals during the rapid-rise portion of the experimental period, with integration of the time-temperature curve by application of the trapezoidal rule to the recorded values. The errors introduced in the corrected temperature rise by the departure of this calculated curve from the true indicated time-temperature curve (obtained occasionally by means of the chronograph) are in part compensating and are negligible in comparison with the total error.

In the heat-of-solution determinations, the materials were dissolved in $600.0 \mathrm{~g}$ of a mixture of $11 \mathrm{ml}$ of 48-percent $\mathrm{HF}$ with $587 \mathrm{~g}$ of $2.000 \mathrm{~N} \mathrm{HNO}_{3}$. The weights of the calorimeter samples were calculated according to the stoichiometry of eq (1), based on a sample weight of $\mathrm{C}_{2} \mathrm{~S}$ of $0.7000 \mathrm{~g}$. This quantity dissolved in $600.0 \mathrm{~g}$ of acid solution gave the same sample ratio as the $0.49 \mathrm{~g}$ of $\mathrm{C}_{2} \mathrm{~S}$ dissolved in $420 \mathrm{~g}$ of solution, found by Brunauer, Kantro, and Weise [8] to give clear solutions and regular values for the heat of solution. The calculated sample weights were $0.7129,0.0461$, and $0.0590 \mathrm{~g}$ for $\mathrm{KC}_{23} \mathrm{~S}_{12}$, calcium sulfate, and potassium sulfate respectively.

In order to make certain that the final calorimeter solutions for the reactants and for the products of eq (1) were identical, both of the reactants were dissolved consecutively in the same solution, the silicate being dissolved first. The same procedure was followed for the products, using a fresh calorimeter charge. Because of the very small heat effects caused by the small samples of $\mathrm{CaSO}_{4}$ and $\mathrm{K}_{2} \mathrm{SO}_{4}$, the calorimeter was heated to approximately the convergence temperature $\left(25.17^{\circ} \mathrm{C}\right)$ before these samples were dissolved, in order to keep the rate of temperature change of the calorimeter as small as possible during the rating periods. The precision of these measurements with small samples was low, since $1-\mathrm{mm}$ deflection on the galvanometer scale corresponded to about 0.04 cal, or about 20 percent of the smallest effect measured. It was thought that the predissolving of $0.7000 \mathrm{~g}$ of $\mathrm{C}_{2} \mathrm{~S}$ (or $0.7129 \mathrm{~g}$ of $\mathrm{KC}_{23} \mathrm{~S}_{12}$ ), corresponding to about 0.008 mole of $\mathrm{CaO}$ and $0.004 \mathrm{~mol}$ of $\mathrm{SiO}_{2}$, might have no detectable effect on the heats of solution of the sulfates, since the calorimeter charge consisted of 0.30 mole of $\mathrm{HF}$, 1.10 mole of $\mathrm{HNO}_{3}$, and 29.10 mole of $\mathrm{H}_{2} \mathrm{O}$. The use of larger samples would result in better precision, although some account might have to be taken of the change of heat of solution with change of sample size. The heats of solution of larger samples, of several sizes, of $\mathrm{CaSO}_{4}$ and $\mathrm{K}_{2} \mathrm{SO}_{4}$ in the nitrichydrofluoric acid mixture were therefore determined without previously dissolving the silicates.

The use of standard substances for the calibration of calorimeters is desirable, since thereby the timetemperature curves during calibration and during use are similar. Such a standard substance for the calibration of heat-of-solution calorimeters using the nitric-hydrofluoric acid mixture [4, 9] is heat-treated zinc oxide of analytical reagent quality. For this purpose the zinc oxide is heated at $950^{\circ} \mathrm{C}$ for $1 \mathrm{hr}$ and ground to pass a No. 100 sieve. A weighed sample is reheated for $5 \mathrm{~min}$ before use and cooled in a desiccator. The heat of solution of this zinc oxide at $25^{\circ} \mathrm{C}$ is $256.6 \mathrm{cal} / \mathrm{g}[4,9]$. This value, however, was determined for a ratio of zinc oxide to acid mixture of $7 / 425$, and the resulting temperature rise is about $4.5^{\circ} \mathrm{C}$. As a useful means of future calibration of such calorimeters for smaller temperature rises, and as a check on the present work, the heat of solution of the standard zinc oxide was determined using samples of 1.56 and $0.20 \mathrm{~g}$ in $600.0 \mathrm{~g}$ of nitrichydrofluoric acid mixture in the electrically calibrated calorimeter. The corresponding temperature rises were about 0.7 and $0.09^{\circ} \mathrm{C}$, respectively.

\section{Experimental Results}

The compositions of the samples as determined by analysis are given in table 1 . It will be seen that from 18 to 36 percent of the $\mathrm{K}_{2} \mathrm{O}$ added was lost by volatilization during the preparation of the samples, the percentage loss increasing with increase of $\mathrm{K}_{2} \mathrm{O}$ 
content. Allowance for the expected loss was made when the samples were proportioned. Six of the completed preparations had ratios of $\left(\mathrm{CaO}+\mathrm{K}_{2} \mathrm{O}\right) /$ $\mathrm{SiO}_{2}$ from $23.88 / 12$ to $24.27 / 12$. The heats of solution of these six samples were used in determining the calculated heats of solution of $\mathrm{C}_{2} \mathrm{~S}$ and $\mathrm{KC}_{23} \mathrm{~S}_{12}$.

The results of the electrical calibrations and the heat-of-solution measurements are given in tables 2 , 3,4 , and 5 . The negative sign before values in these tables indicates that the heat of solution was endothermic. The heats of solution of the eight silicate preparations (table 5) are plotted in figure 1 as a function of the percentage of $\mathrm{K}_{2} \mathrm{O}$ in the samples. The heats of solution of samples $\mathrm{E}$ and $\mathrm{F}$, somewhat deficient in cations, with $(\mathrm{C}+\mathrm{K}) / \mathrm{S}$ ratios of $23.20 / 12$ and $23.32 / 12$, respectively, were less than expected from the values of the other samples. A secondpower curve was drawn through the data of figure 1 by the method of least squares, omitting the data for E. and F. The average experimental heats of solution of $\mathrm{C}_{2} \mathrm{~S}$ and sample $\mathrm{G}$, which was close to $\mathrm{KC}_{23} \mathrm{~S}_{12}$ in composition, were $564.8 \pm 0.19$ and $569.3 \pm 0.50$ $\mathrm{cal} / \mathrm{g}$, respectively (see table 5). The heats of solution of $\mathrm{C}_{2} \mathrm{~S}$ and $\mathrm{KC}_{23} \mathrm{~S}_{12}$ calculated from the equation of the curve, 565.11 and $568.86 \mathrm{cal} / \mathrm{g}$, respectively, were used to determine $-\Delta \mathrm{H}$ of reaction 1 . Brunauer, Hayes, and Hass [10] gave the heat of solution of $\mathrm{C}_{2} \mathrm{~S}$ as $564.0 \pm 2$. cal $/ \mathrm{g}$, and the value taken from figure 2, p. 774 of the paper by Brunauer, Kantro, and Weise [8] is about $565 \mathrm{cal} / \mathrm{g}$. These values are essentially the same as that obtained for $\mathrm{C}_{2} \mathrm{~S}$ in the present work.

\section{TABLE 2. Calibration experiments}

Calorimeter charge, $11 \mathrm{~m}$ of 48 percent $\mathrm{HF}$ solution and $587 \mathrm{~g}$ of $2.000 \mathrm{~N} \mathrm{HNO}_{8}$ Total weight $600.0 \mathrm{~g}$

\begin{tabular}{|c|c|c|c|c|c|}
\hline \multicolumn{2}{|c|}{ Electrical calibrations } & \multicolumn{4}{|c|}{ Heat of solution of zine oxide at $25^{\circ} \mathrm{C}$} \\
\hline $\begin{array}{l}\text { Tempera- } \\
\text { ture rise }\end{array}$ & $\begin{array}{l}\text { Electrical } \\
\text { energy } \\
\text { equivalent }\end{array}$ & $\begin{array}{l}\text { Sample } \\
\text { weight }\end{array}$ & $\begin{array}{l}\text { Heat of } \\
\text { solution }\end{array}$ & $\begin{array}{l}\text { Sample } \\
\text { weight }\end{array}$ & $\begin{array}{l}\text { Heat of } \\
\text { solution }\end{array}$ \\
\hline $\begin{array}{c}\text { Ohms } \\
0.06957_{2} \\
.06937_{1} \\
.06948_{9} \\
.06929_{9} \\
.06921_{4} \\
.06937_{2}\end{array}$ & $\begin{array}{c}\text { cal/Ohm a } \\
5754.1 \\
5757.0 \\
5759.0 \\
5757.3 \\
5761.4 \\
5757.4\end{array}$ & $\begin{array}{l}g \\
\text { 1. } 5619 \\
\text { 1. } 5653 \\
\text { 1. } 5647\end{array}$ & $\begin{array}{c}c a l / g \\
256.82 \\
256.88 \\
257.02\end{array}$ & $\begin{array}{c}g \\
0.2014 \\
.2023 \\
.2021\end{array}$ & $\begin{array}{r}\mathrm{cal} / \mathrm{g} \\
256.8 \\
257.9 \\
256.3\end{array}$ \\
\hline $\begin{array}{l}\text { A verage } \\
\text { S.D. } \\
\% \text { d }\end{array}$ & $\begin{array}{r}\text { b } 5757.7 \\
0.98 \\
.017\end{array}$ & $\begin{array}{l}-- \\
- \\
-\end{array}$ & $\begin{array}{c}256.91 \\
0.06 \\
.023\end{array}$ & - & $\begin{array}{r}257.0 \\
0.48 \\
.19\end{array}$ \\
\hline
\end{tabular}

a $1 \mathrm{cal}=4.184 \mathrm{abs}$ j.

b $d R / d T=0.1010$. The energy equivalent is therefore $581.5 \mathrm{cal} / \mathrm{deg}$.

c S.D. $=$ standard deviation of the average $=\sqrt{\left[\mathbf{\Sigma} x^{2}-(\mathbf{\Sigma} x)^{2} / n\right] / n(n-1)}$.

d Coefficient of variation $=100 \times$ S.D. $/$ (average).

TABLE 3. Heat of solution of $\mathrm{CaSO}_{4}$ (anhydrite) in $600.0 \mathrm{~g}$ of nitric-hydrofluoric acid at $25^{\circ} \mathrm{C}$.

$\left(11 \mathrm{ml}\right.$ of $48 \% \mathrm{HF}$ and $587 \mathrm{~g}$ of $\left.2.000 \mathrm{NHNO}_{3}\right)$

\begin{tabular}{|c|c|c|c|c|c|c|c|}
\hline $\begin{array}{c}\text { Sample } \\
\text { weight }\end{array}$ & $\begin{array}{l}\text { Heat of } \\
\text { solution }\end{array}$ & $\begin{array}{l}\text { Sample } \\
\text { weight }\end{array}$ & $\begin{array}{l}\text { Heat of } \\
\text { solution b }\end{array}$ & $\begin{array}{l}\text { Sample } \\
\text { weight }\end{array}$ & $\begin{array}{l}\text { Heat of } \\
\text { solution c }\end{array}$ & $\begin{array}{l}\text { Sample } \\
\text { weight }\end{array}$ & $\begin{array}{l}\text { Heat of } \\
\text { solution } d\end{array}$ \\
\hline $\begin{array}{c}g \\
2.0175 \\
1.0450 \\
1.0129 \\
1.0017\end{array}$ & $\begin{array}{c}c a l / q \\
-4.31 \\
\mathrm{a}-4.30 \\
-4.14 \\
-4.24\end{array}$ & $\begin{array}{l}g \\
0.5091 \\
.5230 \\
.5049 \\
.5016 \\
.5099\end{array}$ & $\begin{array}{c}\text { cal } / g \\
-4.21 \\
-4.34 \\
-4.59 \\
-4.06 \\
-4.56\end{array}$ & $\begin{array}{c}g \\
0.1014 \\
.1059 \\
.1100 \\
.1082 \\
.1046\end{array}$ & $\begin{array}{l}c a l / g \\
-4.69 \\
-5.22 \\
-5.29 \\
-4.42 \\
-4.19\end{array}$ & $\begin{array}{c}g \\
0.0494 \\
.0498 \\
.0487 \\
.0485 \\
.0449\end{array}$ & $\begin{array}{l}c a l / g \\
-4.2_{3} \\
-2.9_{9} \\
-4.8_{4} \\
-2.0_{4} \\
-7.1_{5}\end{array}$ \\
\hline $\begin{array}{l}\text { 1. } 0024 \\
\text { 1. } 0185\end{array}$ & $\begin{array}{l}-4.13 \\
-4.17\end{array}$ & $\begin{array}{l}.5079 \\
.5096 \\
.5043 \\
.5098 \\
.5150\end{array}$ & $\begin{array}{l}-4.58 \\
-4.28 \\
-4.17 \\
-4.26 \\
-4.21\end{array}$ & $\begin{array}{l}.1073 \\
.1029\end{array}$ & $\begin{array}{l}-5.48 \\
-5.09\end{array}$ & $\begin{array}{l}\text { Average } \\
\text { S.D } \\
\text { V, } \%\end{array}$ & $\begin{array}{r}4.25 \\
0.90 \\
21\end{array}$ \\
\hline
\end{tabular}

a Five 1-g samples dissolved consecutively in a single calorimeter charge.

Ten 1/2-g samples dissolved consecutively in a single calorimeter charge.

- Seven 0.1-g samples dissolved consecutively in a single calorimeter charge.

d $0.71 \mathrm{~g}$ of $\mathrm{K}_{2} \mathrm{O} \cdot 23 \mathrm{CaO} \cdot 12 \mathrm{SiO}_{2}$ predissolved for each determination.

TABLE 4. Heat of solution of $\mathrm{K}_{2} \mathrm{SO}_{4}(\mathrm{c}, 11)$ in $600.0 \mathrm{~g}$ of nitric-hydrofluonc acid at $25^{\circ} \mathrm{C}$.

(11 $\mathrm{ml}$ of $48 \% \mathrm{HF}$ and $587 \mathrm{~g}$ of $2.000 \mathrm{~N} \mathrm{HNO}_{3}$ )

\begin{tabular}{|c|c|c|c|c|c|c|c|}
\hline $\begin{array}{l}\text { Sample } \\
\text { weight }\end{array}$ & $\begin{array}{l}\text { Heat of } \\
\text { solution }\end{array}$ & $\begin{array}{l}\text { Sample } \\
\text { weight }\end{array}$ & $\begin{array}{l}\text { Heat of } \\
\text { solution a }\end{array}$ & $\begin{array}{l}\text { Sample } \\
\text { weight }\end{array}$ & $\begin{array}{l}\text { Heat of } \\
\text { solution a }\end{array}$ & $\begin{array}{l}\text { Sample } \\
\text { weight }\end{array}$ & $\begin{array}{l}\text { Heat of } \\
\text { solution a }\end{array}$ \\
\hline $\begin{array}{c}g \\
2.0708 \\
1.0265 \\
0.5109\end{array}$ & $\begin{array}{l}\mathrm{cal} / \mathrm{g} \\
-43.56 \\
-43.65 \\
-44.40\end{array}$ & 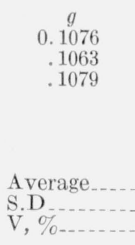 & $\begin{array}{l}c a l / g \\
-44.89 \\
-44.23 \\
-44.64 \\
\\
\\
\\
\\
-44.59 \\
0.19 \\
0.43\end{array}$ & $\begin{array}{c}g \\
0.1038 \\
.1016 \\
.1095 \\
.1028 \\
.1073\end{array}$ & $\begin{array}{c}c a l / g \\
-43.66 \\
-43.05 \\
-41.26 \\
-43.90 \\
-43.60 \\
\\
\\
-43.09 \\
0.48 \\
1.1\end{array}$ & $\begin{array}{c}g \\
0.0609 \\
.0612 \\
.0603 \\
.0575 \\
.0595 \\
.0600\end{array}$ & $\begin{array}{c}c a l / g \\
-40.5 \\
-41.5 \\
-41.7 \\
-42.2 \\
-43.4 \\
-43.5 \\
-42.6 \\
0.25 \\
0.59\end{array}$ \\
\hline
\end{tabular}

a $0.70 \mathrm{~g} 2 \mathrm{CaO} \cdot \mathrm{SiO}_{2}$ predissolved for each determination. 
TABLE 5. Heat of solution at $25^{\circ} \mathrm{C}$. of $2 \mathrm{CaO} \cdot \mathrm{SiO}_{2}(c, \beta)$ and $\mathrm{K}_{2} \mathrm{O}-\mathrm{CaO}-\mathrm{SiO}_{2}$ solid solutrons in $600.0 \mathrm{~g}$ of nitric-hydrofluoric acid (11 $\mathrm{ml}$ of $48 \% \mathrm{HF}$ and $587 \mathrm{~g}$ of $2.000 \mathrm{NHNO}_{3}$ )

\begin{tabular}{|c|c|c|c|c|c|c|c|}
\hline \multicolumn{2}{|c|}{$\beta-2 \mathrm{CaO} \cdot \mathrm{SiO}_{3} \mathrm{a}$} & \multicolumn{2}{|c|}{ A } & \multicolumn{2}{|c|}{ B } & \multicolumn{2}{|c|}{ C } \\
\hline $\begin{array}{l}\text { Sample } \\
\text { weight }\end{array}$ & $\begin{array}{l}\text { Heat of } \\
\text { solution }\end{array}$ & $\begin{array}{l}\text { Sample } \\
\text { weight }\end{array}$ & $\begin{array}{l}\text { Heat of } \\
\text { solution }\end{array}$ & $\begin{array}{l}\text { Sample } \\
\text { weight }\end{array}$ & $\begin{array}{l}\text { Heat of } \\
\text { solution }\end{array}$ & $\begin{array}{l}\text { Sample } \\
\text { weight }\end{array}$ & $\begin{array}{l}\text { Heat of } \\
\text { solution }\end{array}$ \\
\hline $\begin{array}{r}g \\
0.7001 \\
.7013 \\
.7080 \\
.7013 \\
.7031 \\
.7066 \\
.6960 \\
.7025\end{array}$ & $\begin{array}{l}\text { callg } \\
565.3 \\
565.1 \\
564.3 \\
564.9 \\
564.0 \\
564.9 \\
565.6 \\
564.4\end{array}$ & $\begin{array}{r}g \\
0.7315 \\
.7013 \\
.7071 \\
.7110 \\
.7065\end{array}$ & $\begin{array}{r}\text { cal/g } \\
566.2 \\
567.0 \\
565.9 \\
565.4 \\
566.6\end{array}$ & $\begin{array}{r}g \\
0.7131 \\
.7200 \\
.7121 \\
.7105 \\
.7106\end{array}$ & $\begin{array}{r}\text { callg } \\
556.8 \\
568.4 \\
567.3 \\
568.2 \\
568.0\end{array}$ & $\begin{array}{l}g \\
0.7231 \\
.7300 \\
.7227 \\
.7216 \\
.7217 \\
.7218 \\
.7205\end{array}$ & $\begin{array}{l}c a l / g \\
568.3 \\
567.3 \\
566.4 \\
569.4 \\
568.3 \\
568.7 \\
569.1\end{array}$ \\
\hline $\begin{array}{l}\text { Average } \\
\text { S.D } \\
\text { V, } \%\end{array}$ & $\begin{array}{c}564.8 \\
0.19 \\
0.034\end{array}$ & & $\begin{array}{c}566.2 \\
0.28 \\
0.049\end{array}$ & & $\begin{array}{c}568.1 \\
0.25 \\
0.044\end{array}$ & & $\begin{array}{l}568.2 \\
0.40 \\
0.070\end{array}$ \\
\hline \multicolumn{2}{|c|}{ D } & \multicolumn{2}{|c|}{$\mathrm{E}$} & \multicolumn{2}{|c|}{$\mathrm{F}$} & \multicolumn{2}{|c|}{ G } \\
\hline $\begin{array}{r}0.7466 \\
.7497 \\
.7475 \\
.7440 \\
.7450 \\
.7433 \\
.7442\end{array}$ & $\begin{array}{l}568.3 \\
565.0 \\
568.4 \\
568.7 \\
570.2 \\
568.5 \\
568.9\end{array}$ & $\begin{array}{r}0.7969 \\
.7930 \\
.7888 \\
.7985 \\
.7923 \\
.7950 \\
.7942\end{array}$ & $\begin{array}{l}567.1 \\
566.7 \\
565.1 \\
566.1 \\
566.2 \\
567.3 \\
568.3\end{array}$ & $\begin{array}{r}0.7714 \\
.7760 \\
.7680 \\
.7671 \\
.7698 \\
.7663 \\
.7672\end{array}$ & $\begin{array}{l}568.0 \\
568.2 \\
567.4 \\
569.5 \\
567.9 \\
568.8 \\
568.1\end{array}$ & $\begin{array}{r}0.7143 \\
.7169 \\
.7158 \\
.7125 \\
.7087 \\
.7410 \\
.7468 \\
.7407 \\
.7401 \\
.7461\end{array}$ & $\begin{array}{c}568.0 \\
568.4 \\
569.0 \\
566.8 \\
568.5 \\
570.3 \\
569.9 \\
572.6 \\
570.1 \\
569.2 \\
569.3 \\
0.50 \\
0.088\end{array}$ \\
\hline
\end{tabular}

a Weighed in platinum crucible, heated $3 \frac{1}{2} \mathrm{hr}$ at $1,050^{\circ} \mathrm{C}$, cooled in a desiccator, and reweighed before introduction.

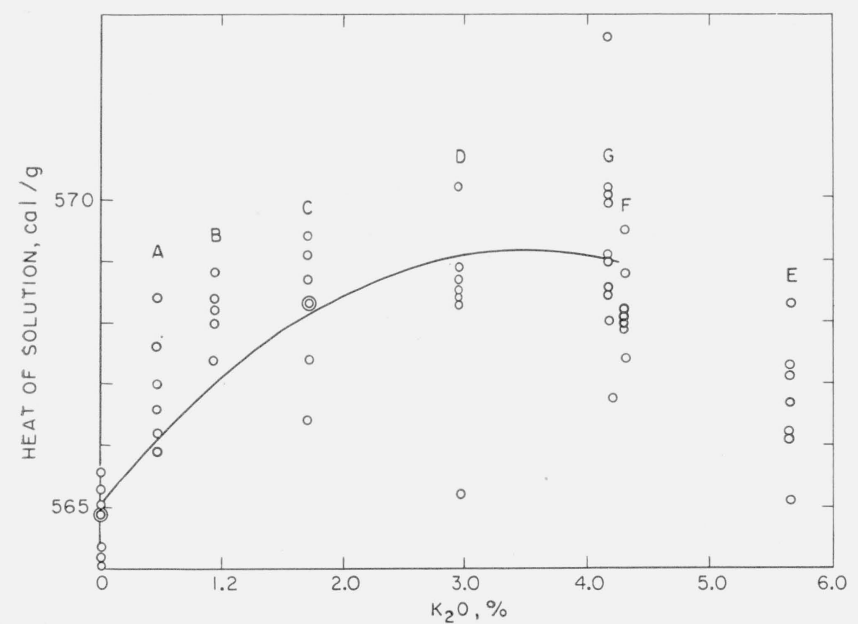

FIGURE 1. Heats of solution of potassium-calcium-silica solid solutions.

The heat of solution of $\mathrm{CaSO}_{4}$ (table 3 ) does not seem to be significantly affected by sample size or by the presence of predissolved $\mathrm{KC}_{23} \mathrm{~S}_{12}$. However, the average value $-4.25 \pm 0.90 \mathrm{cal} / \mathrm{g}$ obtained using the $0.049-\mathrm{g}$ samples was used in calculation. The standard deviation was large, as was expected for small samples, but the average value is about the same as determined for larger samples without predissolving the silicate. The experimental values are substantially different than the calculated [11] heat of solution of $\mathrm{CaSO}_{4}$ in water to form $\mathrm{CaSO}_{4}$, $100000 \mathrm{H}_{2} \mathrm{O} \quad\left(0.045 \mathrm{~g} \quad \mathrm{CaSO}_{4} / 600\right.$ g $\left.\mathrm{H}_{2} \mathrm{O}\right) . \quad+30.1$ $\mathrm{cal} / \mathrm{g}$, or the value calculated by Brunauer et al.
[10] for the heat of solution in nitric-hydrofluoric acid, $+31.2 \mathrm{cal} / \mathrm{g}[10]$.

The endothermic heat of solution of $\mathrm{K}_{2} \mathrm{SO}_{4}$ seemed to increase slightly with decrease in sample size (table 4). The presence of predissolved $\mathrm{C}_{2} \mathrm{~S}$ also seemed to have a slight effect which a $t$-test [12] showed to be significant at the 5-percent level (comparing the two sets of measurements made with 0.1 $\mathrm{g}$ samples, $\left.t=2.65, t_{\text {crit }}=2.447\right)$. For the calculation of $-\Delta \mathrm{H}$ of reaction 1 , the value $-42.6 \pm 0.25 \mathrm{cal} / \mathrm{g}$ obtained with $0.06-\mathrm{g}$ samples was used for the heat of solution of potassium sulfate. The calculated value of the heat of solution of $\mathrm{K}_{2} \mathrm{SO}_{4}$ in water to form $\mathrm{K}_{2} \mathrm{SO}_{4} .1000000 \mathrm{H}_{2} \mathrm{O}\left(0.058 \mathrm{~g} \mathrm{~K}_{2} \mathrm{SO}_{4} / 600 \mathrm{~g}\right.$ $\left.\mathrm{H}_{2} \mathrm{O}\right)$ is $-32.9 \mathrm{cal} / \mathrm{g}[11]$.

The standard value of $256.6 \mathrm{cal} / \mathrm{g}$ for the heat of solution of zinc oxide in the nitric-hydrofluoric acid mixture at $25^{\circ} \mathrm{C}[4,9]$ was obtained as the result of tests made with the present calorimeter (using a shorter galvanometer-scale distance) [13] combined with the measurements of Stenzel and Morris [14] at $30^{\circ} \mathrm{C}$. The values $257.0 \pm 0.48$ and $256.91 \pm .06$ $\mathrm{cal} / \mathrm{g}$ given in table 2 for $\mathrm{ZnO} /$ solution ratios of $0.2 / 600$ and $1.58 / 600$, respectively, agree well with the standard value for which the calculated ratio is $9.88 / 600$. These three values of the heat of solution of zinc oxide lie very close to the line $y=257.0$ $-23.5 x$, where $y$ is the heat of solution of zinc oxide in calories per gram, and $x$ is the zinc-oxide per solution weight ratio. Values calculated from this equation can safely be used to calibrate the calorimeter for temperature rises smaller than the $4.5^{\circ}$ for which the standard value is given. 


\section{Heats of Formation}

The heat of reaction $(\Delta \mathrm{H})$ of eq (1) at $25^{\circ} \mathrm{C}$ is calculated to be $-36.3 \pm 1.4 \mathrm{kcal}$, using the heats of solution given in section 3 and the 1952 atomic weights [15]. The heats of formation of $2 \mathrm{CaO}$. $\mathrm{SiO}_{2}(\mathrm{c}, \beta), \mathrm{CaSO}_{4}$ (c, anhydrite), and $\mathrm{K}_{2} \mathrm{SO}_{4}(\mathrm{c}, \mathrm{II})$ are $-538.0,-342.42$, and $-342.66 \mathrm{kcal} / \mathrm{mole}$ respectively, at $25^{\circ} \mathrm{C}$ [11]. The heat of formation of $\mathrm{K}_{2} \mathrm{O} \cdot 23 \mathrm{CaO} \cdot 12 \mathrm{SiO}_{2}(\mathrm{c})$, therefore, is $-6420 \mathrm{kcal} /$ mole.

\section{Summary}

The heats of solution of $2 \mathrm{CaO} \cdot \mathrm{SiO}_{2}(\mathrm{c}, \beta), \mathrm{CaSO}_{4}(\mathrm{c})$, $\mathrm{K}_{2} \mathrm{SO}_{4}(\mathrm{c}, \mathrm{II})$, and $\mathrm{K}_{2} \mathrm{O} \cdot 23 \mathrm{CaO} \cdot 12 \mathrm{SiO}_{2}(\mathrm{c})$ were determined in a mixture of $2.000 \mathrm{~N}$ nitric acid and 48percent hydrofluoric acid in an isothermal-jacket calorimeter. From these and other data in the literature, the heat of formation of $\mathrm{K}_{2} \mathrm{O} \cdot 23 \mathrm{CaO}$. $12 \mathrm{SiO}_{2}$ (c) from the elements was calculated to be $-6420 \mathrm{kcal} / \mathrm{mole}$ at $25^{\circ} \mathrm{C}$.

WAshington, January 6, 1959.

\section{References}

[1] T. F. Newkirk, J. Research NBS 47, 349 (1951) RP2261.

[2] W. C. Tavlor, J. Research NBS 27, 311 (1941) RP1421.

[3] Y. Suzukawa, Zement-Kalk-Gips 9, 390 (1956).

[4] Federal Test Method Standard No. 158, Cements, hydraulic, sampling, inspection, and testing (General Services Administration, Washington 25, D. C., 1957).

[5] E. S. Newman and L. S. Wells, J. Research NBS 20, 825 (1938) RP1107.

6] E. S. Newman, J. Research NBS 54, 347 (1955) RP2597.

[7] E. S. Newman, J. Research NBS 5\%, 27 (1956) RP2690.

[8] S. Brunauer, D. L. Kantro, and C. H. Weise, J. Phys. Chem. 60, 771 (1956).

[9] ASTM Standards, 1952, Part 3, p. 149 (Am. Soc. for Testing Materials, Philadelphia, Pa., 1953).

[10] S. Brunauer, J. C. Hayes, and W. E. Hass, J. Phys. Chem. 58, 279 (1954).

[11] F. D. Rossini, D. D. Wagman, W. H. Evans, S. Levine, and I. Jaffe, Selected values of chemical thermodynamic properties, NBS Circ. 500 (1952).

[12] W. J. Youden, Statistical methods for chemists, p. 25 (John Wiley \& Sons, Inc., New York, N. Y., 1951).

[13] Leo Shartsis and E. S. Newman, Proc. Am. Soc. Testing Materials 43, 905 (1943).

[14] R. W. Stenzel and S. B. Morris, Ind. Eng. Chem., Anal. Ed. 6, 246 (1934).

[15] E. Wichers, J. Am. Chem. Soc. 74, 2447 (1952). 